\title{
Keperawatan bencana: pengurangan risiko bencana tsunami melalui komunitas mangrove
}

\section{Disaster nursing: tsunami disaster risk reduction through Mangrove community}

\author{
Putra Agina Widyaswara Suwaryo $^{1^{*}}$, Sarwono $^{2}$, Podo Yuwono ${ }^{3}$ \\ ${ }^{1,2,3}$ STIKES Muhammadiyah Gombong, Kebumen, Jawa Tengah \\ 1ners.putra@gmail.com*; ${ }^{2}$ ronifah@gmail.com; ${ }^{3}$ maz.phdh@gmail.com \\ *corresponding author
}

Tanggal Submisi: 10 September 2020, Tanggal Penerimaan: 8 Agustus 2020

\begin{abstract}
Abstrak
Pengurangan risiko bencana perlu melibatkan berbagai pihak, seperti masyarakat, lembaga dan organisasi tertentu dan pemerintah. Kajian terkait mangrove membuktikan bisa memberikan kontribusi yang tinggi menjadi benteng alami dari tsunami. Tujuan penelitian ini untuk mengetahui rencana, implementasi dan peran perawat dalam keperawatan bencana untuk pengurangan risiko bencana tsunami. Penelitian ini menggunakan desain kualitatif. Proses pengambilan data menggunakan wawancara dan Focus Group Discussion (FGD) terhadap 5 partisipan yang terdiri dari tenaga medis yaitu perawat dan orang awam. Peran perawat dalam pengurangan risiko bencana tsunami sebagai pemimpin, pendidik, penanggap, dan membantu komunikasi dalam membuat kebijakan dengan pemerintah.
\end{abstract}

Kata kunci: bencana tsunami; mangrove; keperawatan bencana

\begin{abstract}
Disaster risk reduction needs to involve various parties, such as the community, certain institutions and organizations and the government. Mangrove-related studies prove that they can make a high contribution to becoming a natural fortress from the tsunami. The purpose of this study was to determine the plan, implementation and role of nurses in disaster nursing for tsunami risk reduction. This study uses a qualitative design. The data collection process used interviews and Focus Group Discussion (FGD) of 5 participants consisting of medical personnel namely nurses and lay people. The role of nurses in tsunami risk reduction as leaders, educators, responders, and assisting in communication in making policy with the government.
\end{abstract}

Keywords: mangrove; nursing disaster; tsunami disaster 


\section{PENDAHULUAN}

Bencana alam yang terjadi di Indonesia pada satu dekade terakhir menimbulkan kerugian, baik korban jiwa maupun harta benda. Bencana tersebut bukan yang pertama kali terjadi, sehingga memerlukan perhatian dan penanganan khusus dari berbagai pihak karena bisa bencana yang sama dengan dampak yang lebih besar berulang tiap tahunnya. Pengurangan risiko bencana bisa dilakukan untuk mengurangi jumlah korban jiwa dan kerugian harta benda. Kajian lebih lanjut, bencana juga memberikan dampak terhadap perekonomian. Anggaran belanja tidak terduga yang dibuat oleh Badan Penanggulangan Bencana Daerah (BPBD) tiap tahun terus meningkat, sedangkan Alokasi Pendapatan dan Belanja Daerah (APBD) dalam kegiatan Pengurangan Risiko Bencana (PRB) masih sangat rendah yaitu sekitar 0.1 persen (Suwaryo \& Yuwono, 2017; Widayatun \& Fatoni, 2013). Hal ini dikarenakan peningkatan anggaran nasional tidak diikuti dengan anggaran pengurangan risiko bencana di daerah. Dalam satu tahun terakhir tercatat 3.466 kejadian bencana dengan jumlah korban 10.2 juta orang. Jawa tengah menduduki peringkat teratas yaitu 304 kejadian bencana (Scholten et al., 2014; Widayatun \& Fatoni, 2013).

Dalam manajemen bencana, mitigasi menjadi salah satu langkah awal yang perlu dilakukan sebelum terjadi bencana. Rencana mitigasi memainkan peran penting dalam mendukung pengurangan risiko bencana dan ketahanan jangka panjang suatu wilayah atau negara. Undang-undang Mitigasi Bencana tahun 2000 mewajibkan semua negara bagian untuk menyiapkan rencana mitigasi (Paidi, 2012). Beberapa program pemerintah yang mendukung mitigasi bencana sangat diperlukan. Seperti yang tertuang dalam Undang-undang nomor 24 tahun 2007, tentang penanggulangan bencana, dimana pemerintah harus memberikan perlindungan kepada masyarakat dari ancaman bencana. Sedangkan pemerintah daerah, memiliki tanggungjawab untuk melakukan kegiatan dalam rangka pengurangan risiko bencana dan pemaduan pengurangan risiko bencana dengan program pembangunan (Baack \& Alfred, 2013; Lindell, 2013; Petrini, 2014).

Studi kesiapsiagaan mitigasi bencana perlu melibatkan berbagai pihak, seperti masyarakat, lembaga dan organisasi tertentu dan pemerintah. Keterlibatan tersebut meliputi perencanaan, pendidikan dan pelatihan kepada masyarakat yang secara langsung berada pada wilayah tertentu dengan risiko bencana tertentu. Pada tahun 2004, pengembangan program dan pesan radio untuk meningkatkan ketahanan terhadap bencana dilakukan di Aceh pasca bencana tsunami. Jaringan komunitas dan sosial selama situasi bencana sangat penting, terutama untuk melakukan komunikasi dan koordinasi serta distribusi bantuan ketika terjadi bencana (Leodoro J. Labrague et al., 2016; Park \& Kim, 2017; Veenema et al., 2016).

Peningkatan global dalam bencana alam yang disebabkan oleh manusia telah meminta perhatian pada bagian yang dimainkan oleh penyedia layanan kesehatan dalam mitigasi bencana. Tenaga kesehatan seperti dokter, perawat dan tenaga medis yang lain memiliki peran dalam pengelolaan sumber daya yang tinggal di wilayah bencana. beberapa tenaga medis menyampaikan bahwa sebagian besar tidak percaya diri dengan kemampuannya dan tidak tahu bagaimana merespon peristiwa bencana yang besar. Beberapa persiapan dalam rangka mitigasi yang bisa dilakukan adalah memberikan latihan rutin, pendidikan kesehatan dan simulasi lanjut khusus untuk kesiapan bencana, serta pembentukan komunitas relawan antar tenaga kesehatan (Baack \& Alfred, 2013; Husna et al., 2011; Nilsson et al., 2016).

Kajian terkait mangrove membuktikan bisa memberikan kontribusi yang tinggi dalam menjaga stok pangan pesisir dan benteng alami dari tsunami. Hampir seperempat bagian 
mangrove dunia atau sedikitnya 3.5 juta hektar lahan mangrove berada di Indonesia (Saintilan et al., 2014). Salah satu faktor yang membuat kerusakan yang terjadi pada ekosistem mangrove adalah pengelolaan yang tidak dilakukan dengan baik. Perlu dikaji mengenai tata kelola dan pemanfaatan ekosistem mangrove serta menelaah regulasi yang ada terkait ekosistem mangrove (Rasmeemasmuang \& Sasaki, 2015; Saw \& Kanzaki, 2015).

Usulan lain untuk mempertahankan ekosistem mangrove yaitu promosi pengelolaan ekosistem mangrove, mengatasi adaptasi dan mitigas perubahan iklim, pemulihan hutan mangrove dan ekosistem terdegradasi, meningkatkan mata pencaharian masyarakat terkait mangrove, penguatan tata kelola, penegakan hukum dan sistem pemantauan, valuasi jasa lingkungan dan penelitian dan pendidikan untuk pembangunan berkelanjutan ekosistem mangrove (Giri et al., 2015; Sierra-Correa \& Cantera Kintz, 2015).

Berikut adalah fakta tentang mangrove di Indonesia 1) hampir seperempat dari seluruh ekosistem mangrove dunia berada di Indonesia, mencakup 2.9 juta hektar, hampir sebesar wilayah belgia. 2) hutan mangrove Indonesia menyimpan lima kali lebih banyak karbon disbanding hutan daratan, dan sepertiga dari seluruh karbon yang tersimpan dalam ekosistem pesisir global. Tersimpan lebih dari tiga miliar ton karbon, setara dengan hanya 20 tahun emisi bahan bakar fosil Indonesia tingkat penggunaan 2011. 3) area seluas New York 55.000 hektar mangrove Indonesia - menghilang tiap tahun. Akuakultur bertanggungjawab atas 40 persen kehilangan mangrove. 4) emisi tahunan dari kerusakan mangrove indonesia sebesar dengan 190 juta ton, setara dengan seluruh 9.5 juta mobil penumpang di Indonesia berjalan keliling dunia dua kali. Lebih dari 40 persen emisi global dari kerusakan ekosistem pesisir, termasuk semak, mangrove dan rumput laut, berasal dari kerusakan mangrove di Indonesia. 5) menghentikan kerusakan mangrove dapat memenuhi seperempat dari target reduksi emisi Indonesia, yaitu sebesar 26 persen pada 2020. Ini setara dengan mengurangi 40 juta mobil di jalanan (Lovelock et al., 2015; Rogers et al., 2016).

Pada International Society for Mangrove Ecosystem (ISME) merumuskan aksi serius tentang ekosistem mangrove dan membahas contoh action plan yang sudah dilakukan sejumlah komunitas dan berdampak penting. Salah satu solusi yang disampaikan adalah pengelola lahan mangrove yang terdiri dari 272 peserta dari 24 negara mendorong untuk membuat kebijakan, perencana lahan, praktisi dan ilmuwan bidang mangrove, serta organisasi lainnya menggandakan usaha untuk bekerja dengan komunitas pesisir. Untuk memastikan konservasi, restorasi, perlindungan dan pengelolaan berkelanjutan sisa ekosistem mangrove dunia (Lovelock et al., 2015; Scholten et al., 2014).

Sebagai tenaga Kesehatan, Perawat hendaknya mengambil peran pada lini terdepan dalam berbagai tahapan mulai tahap pra bencana, bencana dan pasca bencana. Tahapan pra bencana merupakan bentuk antisipasi dalam mencegah bencana berserta dampaknya (Doondori \& Paschalia, 2021). Fenomena bencana tersebut kemudian diambil oleh beberapa tenaga medis yang ada di wilayah kebumen menjadi sebuah ide untuk membentuk komunitas yang terdiri dari lintas disiplin ilmu kesehatan dan orang awam untuk menanam dan mengelola lahan mangrove yang sudah ada. Oleh karena itu, perlu dikaji lebih lanjut terkait tata kelola dan pemanfaatan ekosistem mangrove yang diinisiasi oleh tenaga kesehatan di wilayah kebumen. 


\section{METODE}

Penelitian ini menggunakan metode kualitatif yang mendeskripsikan tata kelola dan pemanfaatan serta regulasi yang ada termasuk koordinasi, integrasi dan kerjasama dalam implementasi pengelolaan ekosistem mangrove yang efektif dan efisien. Data deskriptif berupa transkip wawancara dari masing-masing partisipan dan rekaman hasil wawancara dalam bentuk suara (mp3). Penelitian ini tidak melakukan survey atau penilaian langsung ke lapangan terkait kondisi ekosistem mangrove. Teknik perolehan data untuk menjawab masalah penelitian didasarkan pada rencana dan implementasi yang sudah dilakukan dalam pengelolaan ekosistem mangrove, peran perawat dalam mitigasi bencana, dokumentasi kebijakan atau regulasi yang ada, wawancara mendalam (indepth interview) dan Focus Group Discussion (FGD) dengan partisipan. Teknik analisis data menggunakan teknik analisis kualitatif dan dilakukan secara interaktif serta berlangsung terus menerus sampai tuntas. Aktifitas dalam analisis meliputi reduksi data, penyajian data dan penarikan kesimpulan. Partisipan berjumlah 5 orang yang terdiri dari tenaga medis atau perawat dan orang awam yang berasal dari beberapa wilayah dan tinggal di sekitar pantai. Penelitian dilakukan di kabupaten kebumen.

\section{HASIL DAN PEMBAHASAN}

Pengelolaan ekosistem mangrove di Kebumen dilakukan oleh pemerintah dan komunitas mangrove, serta bekerjasama dengan Lembaga Penanggulangan Bencana Muhammadiyah. Hal tersebut disampaikan berdasarkan hasil wawancara terhadap partisipan.

"awal komunitas mangrove dibentuk sebagai inisiasi dan kesadaran kami terhadap kekhawatiran bencana tsunami" (P1)

"kami sadar, perlu ada yang bergerak untuk mengurangi dampak karena bencana tsunami” (P3)

“....melihat tingginya intensitas hujan dan kenaikan air laut serta gempa yang berasal dari laut, kami tergerak untuk membentuk sebuah komunitas yang bisa mengurangi korban karena bencana tsunami" (P4).

Pembentukan komunitas mangrove tersebut juga menjadi salah satu komunitas baru yang memiliki peran dalam pengurangan risiko bencana tsunami di wilayah kebumen. Komunitas tersebut kemudian berperan aktif untuk melakukan koordinasi dan kolaborasi dengan relawan dan komunitas lain yang memiliki tujuan yang sama.

“... komunitas mangrove ini masih baru, karena baru dibentuk pada 31 juli kemarin”

“....kami sudah agendakan untuk diskusi dengan BPBD dan beberapa relawan yang ada dikebumen" (P2)

"rencana berikutnya adalah kolaborasi dengan relawan lain untuk pengelolaan mangrove yang sudah ada” (P4) 
“....kemarin kami ditawari bibit pohon mangrove untuk segera ditanam, dan sudah disiapkan lahannya” (P5)

Rencana kegiatan dalam rangka pengurangan risiko bencana dibuat bersama-sama antara komunitas mangrove, warga dan pemerintah atau BPBD. Beberapa program sudah dibentuk untuk kemudian direalisasikan.

"terakhir kami ikut sosialisasi dan penyuluhan tentang perawatan mangrove" (P2)

"kami juga diajak untuk membuat peta atau alur ketika terjadi tsunami" (P3)

“BPBD mengajak untuk membuat vegetasi di kawasan pesisir....” (P4)

"kami juga ikut memberikan pemeriksaan kesehatan pada kegiatan penyuluhan dan sosialisasi tentang kebencanaan” (P5)

Kendala juga dialami oleh komunitas mangrove dalam melaksanakan rencana serta program yang sudah dibuat. Salah satunya adalah kesadaran masyarakat sekitar kawasan mangrove yang perlu ditingkatkan sehingga bisa bersama-sama merawat keberlangsungan hidup ekosistem mangrove, dalam rangka mengurangi dampak akibat bencana tsunami.

"kami kesulitan untuk menyadarkan masyarakat, terutama mereka yang memiliki tambak udang di kawasan pesisir pantai" (P1)

“beberapa dari mereka merusak bibit mangrove yang baru ditanam” (P3)

“... Mangrove yang baru ditanam rusak terkena gelombang air laut” (P4)

Tenaga medis atau perawat juga memiliki peran penting dalam kesiapsiagaan dalam bencana. Peran perawat sebagai pemimpin, pendidik, penanggap, pembuat kebijakan dan peneliti kesiapsiagaan dan respon bencana.

"bencana tanah longsor kemarin kami ditugaskan langsung oleh Rumah Sakit untuk memberikan pertolongan kepada korban bencana" (P2)

"....lebih dari 2 kali ikut dalam sosialisasi dan penyuluhan kepada warga tentang pentingnya menjaga alam dan kesehatan sebelum terjadi bencana” (P3)

“....saya paling semangat kalau diminta untuk terjun langsung ke lokasi bencana membantu korban bencana” (P4)

Tantangan terkait dengan alokasi sumber daya untuk mengurangi dampak akibat bencana menginspirasi dalam pembentukan sebuah komunitas tertentuk untuk melakukan kegiatan mitigasi bencana. Keterlibatan berbagai pihak menjadi bagian penting dalam mitigasi bencana dan pengurangan risiko bencana. Hal ini yang menjadi inisiasi beberapa tenaga medis untuk berperan serta dan memberikan kontribusi secara langsung kepada masyarakat diluar layanan kesehatan. Hasil identifitakasi dari total anggota komunitas mangrove yang berjumlah 15 orang, 7 orang terdiri dari tenaga medis yaitu perawat. 


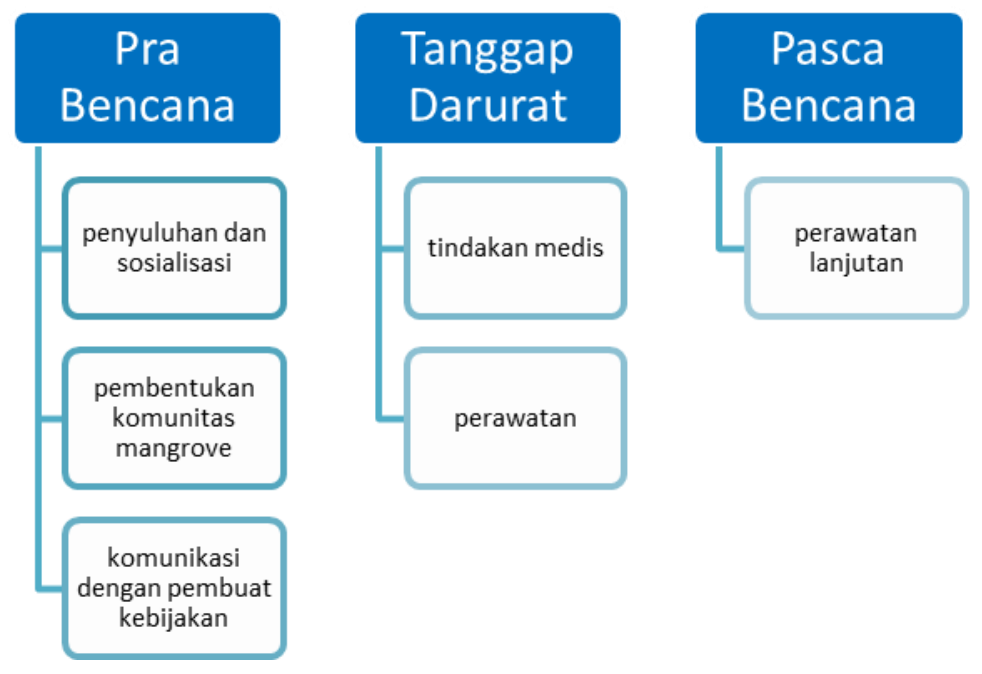

Gambar 1. Peran Perawat dalam Keperawatan Bencana

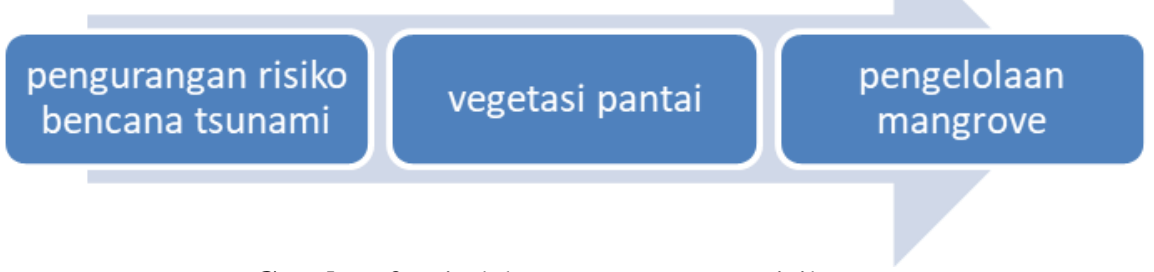

Gambar 2. Tindakan Pengurangan Risiko Bencana

Pengelolaan ekosistem mangrove sudah dilakukan dan melibatkan warga sekitar yang tinggal di pesisir pantai. Masyarakat lokal memiliki peran yang sangat penting dalam merawat dan mengelola ekosistem mangrove. Perawatan dan pengembangan ekosistem mangrove yang dikelola mandiri oleh masyarakat maka akan dengan sendirinya membentuk sebuah komunitas yang fokus mengelola mangrove. Pengelolaan ekosistem mangrove merupakan salah satu program pengurangan risiko bencana yang bersifat konservatif. Program ini tidak akan berjalan efektif tanpa dukungan infrastruktur yang memadai. BPBD mendukung penuh program tersebut, terutama dari divisi pencegahan dan pengurangan risiko bencana (Ahmed \& Glaser, 2016; Rasmeemasmuang \& Sasaki, 2015).

Kesadaran semakin membesar ketika kembali mengingat kejadian tsunami samudra hindia pada tahun 2004 silam. Kota aceh menjadi saksi dan wilayah terdampak parah akibat bencana tersebut. Terlepas dari kenyataan bahwa populasi beberapa negara seperti Chili dan Jepang sadar akan peristiwa semacam itu, banyak tempat lain yang hampir tidak pernah mendengar tentang fenomena seperti itu sebelum tahun 2004. Berulangnya tsunami besar dalam beberapa tahun terakhir telah menyebabkan negara semakin tinggi dalam level kesadaran akan bencana tsunami dibanyak wilayah dunia (Esteban et al., 2013; Hammad et al., 2011; Maza et al., 2015). Hal ini bisa dilihat dari peningkatan pengetahuan, kesiapsiagaan bencana dan kemauan penduduk setempat untuk mengungsi ketika ancaman dari peristiwa tersebut muncul. Namun respon dari beberapa masyarakat terhadap peringatan tsunami saat ini tampaknya masih belum memadai, menunjukkan kurangnya kesadaran oleh setidaknya beberapa individu, ketergantungan berlebihan pada mekanisme pertahanan atau kurangnya 
transmisi pengetahuan dari peristiwa sebelumnya (Husna et al., 2011). Kebutuhan untuk perbaikan substansial akibat tsunami seperti kemampuan perkiraan waktu nyata dan jangka panjang tsunami, pendidikan, pengembangan komunitas yang tahan tsunami atau komunitas lain dalam rangka pengurangan risiko bencana akibat tsunami, serta kemajuan penelitian dan kesiapsiagaan pra bencana semakin meningkatv(Baeda et al., 2015; Leodoro J. Labrague et al., 2016).

Berdasarkan identifikasi kebijakan pengurangan risiko bencana dan strategi adaptasi masyarakat dalam menghadapi bencana, dapat diketahui regulasi pemerintah harus menekankan kepada pemanfaatan sumber daya yang ada dilingkungan sekitar sebagai kapasitas dalam upaya pengurangan risiko bencana, bisa dengan pemberdayaan kelompok masyarakat yang sudah dibentuk oleh BPBD yaitu Desa Tangguh Bencana (Destana) (Loke \& Fung, 2014; Rizqillah \& Suna, 2018).

Tingkat pengetahuan dan pemahaman masyarakat mengenai ancaman bencana harus terus ditingkatkan secara berkala melalui program pelatihan, penyuluhan dan pembentukan kelompok atau komunitas bencana dan berbagai program yang fokus pada pengembangan sumber daya manusia yang lain. Aspek sumber daya manusia bisa ditingkatkan dari segi pendidikan, kesadaran menjaga lingkungan dan perekonomian. Berbagai edukasi, pendidikan kesehatan, simulasi dan pelatihan dilakukan untuk meningkatkan kapasitas masyarakat dalam rangka pengurangan risiko bencana (Baack \& Alfred, 2013; Hanes, 2016; Veenema et al., 2016).

Selain itu, dari sisi tenaga medis atau perawat itu sendiri juga perlu ditingkatkan terkait pengetahuannya tentang kesiapsiagaan bencana. kurangnya penerimaan kompetensi inti dan tidak adanya kesiapsiagaan bencana dalam kurikulum keperawatan menjadi alasan bahwa pengetahuan tersebut perlu selau ditingkatkan (Al Thobaity et al., 2015; Loke \& Fung, 2014). Namun, beberapa perawat yang bekerja di Rumah Sakit militer justru lebih banyak memiliki pengetahuan terkait bencana daripada mereka yang bekerja di Rumah Sakit milik pemerintah atau swasta. Banyak pelatihan yang diwajibkan kepada para anggota militer termasuk tenaga kesehatan untuk aktif dalam kegiatan kebencanaan (Sonneborn et al., 2018; Tzeng et al., 2016).

Dalam dunia pendidikan, keperawatan bencana belum menemukan keseragaman kompetensi yang dimaksudkan diantara studi, meskipun semua studi menggunakan sumber dari organisasi nasional dan internasional. Beberapa sudah memasukkan metode eklektik termasuk penggunaan teknologi, sisanya sudah memasukkan simulasi dengan melibatkan simulator virtual dan aktor secara langsung. Konten dan isi program sangat bervariasi tetapi masih fokus pada prinsip-prinsip umum manajemen bencana dan sesuai untuk tingkat pendidikan (Alfred et al., 2015; Kalanlar, 2018; Kuniayanti, 2012).

Pentingnya peningkatan kapasitas perawat dalam memberikan penanganan kepada korban bencana adalah agar menyelamatkan lebih banyak korban bencana dan membuat mereka tetap bertahan. Karena perawat atau tim medis sebagai pintu gerbang pertama dalam memberikan perawatan korban bencana (Hammad et al., 2011; Usher \& Mayner, 2011). Bahkan beberapa tim medis, terutama perawat memiliki kapasitas terbatas untuk merespon secara efektif dan efisien ketika terjadi bencana. peningkatan kemampuan yang komprehensif tentang keperawatan bencana dengan pendidikan keperawatan bencana yang sistematis dan pelatihan yang professional menjadi alternatif untuk meningkatkan kapasitasn perawat dalam penanganan korban bencana (Rasmeemasmuang \& Sasaki, 2015; Tzeng et al., 2016). 
Pengelolaan mangrove merupakan bagian dari strategi adaptasi yang bersifat swadaya dengan kebutuhan sumber dana yang minimal, namun bisa optimal dalam mengurangi risiko bencana yang ada. Hal ini sedikit berbeda dengan berbagai kebijakan dan program pemerintah daerah yang bersifat fisik seperti pembangunan sabuk pantai, alat pemecah ombak, dan tanggul serta yang lainnya, yang membutuhkan anggaran tidak sedikit, dan memiliki keberlanjutan yang sangat bergantung pada perawatan bangunan tersebut (Li et al., 2015; Rogers et al., 2016; Saw \& Kanzaki, 2015).

Vegetasi pantai bertindak sebagai penghalang alami terhadap aktifitas ekstrim dan antropogenik yang ektstrim, melindungi infrastruktur dan kehidupan manusia. Pembangunan infrastruktur keras untuk perlindungan tsunami tidak memungkinkan di negara berkembang karena sifatnya yang intensif biaya. Penanaman mangrove menjadi salah satu alternatif untuk mengatasi masalah atau mengurangi dampak akibat bencana tsunami. Selain itu, pembentukan vegetasi dan memilih spesies yang sesuai serta struktur strip vegetasi untuk perlindungan tsunami juga penting (Maza et al., 2015; Yan et al., 2015).

Tenaga medis yaitu perawat memiliki peran penting dalam mengembangkan masa depan keperawatan bencana, mengidentifikasi hambatan dan fasilitator untuk mencapai visi dan mengembangkan rekomendasi dalam praktik keperawatan, pendidikan, kebijakan dan penelitian (Ahayalimudin \& Osman, 2016; Baack \& Alfred, 2013; Veenema et al., 2016). Perawat dan organisasi atau kolegium terkait seperti keperawatan gawat darurat dan bencana memiliki keterlibatan dalam dialog nasional yang luas tentang bagaimana cara terbaik memasukkan visi dan rekomendasi ke dalam kehidupan individu mereka dan organisasi tempat mereka bekerja (L. J. Labrague et al., 2018). Hal ini menjadi potensi tersendiri mengingat perawat adalah tenaga kesehatan terbesar dan ada peluang untuk memperkuat kesiapan bencana, meningkatkan kapasitas dan membangun ketahanan masyarakat terhadap bencana.

\section{SIMPULAN}

Peran perawat dalam keperawatan bencana untuk pengurangan risiko bencana tsunami sebagai pemimpin, pendidik, penanggap, dan membantu komunikasi dalam membuat kebijakan dengan pemerintah dalam kesiapsiagaan dan respon bencana. Bahkan sebagai penggerak untuk meningkatkan kesadaran masyarakat. Selain itu, pembentukan komunitas mangrove dalam rangka mengurangi dampak akibat bencana menjadi langkah tersendiri yang melibatkan berbagai pihak untuk menanam dan mengelolan ekosistem mangrove itu sendiri. Perlunya sinergisitas dan kolaborasi untuk memaksimalkan konsep manajemen bencana pada tahap pra bencana yaitu mitigasi.

\section{SARAN}

Perlu adanya peningkatan kapasitas pengetahuan dan kemampuan perawat dalam menghadapi bencana melalui penyeragaman kompetensi dalam bidang Pendidikan, dan peningkatan skills dalam dunia kerja. Pengetahuan dan kesadaran masyarakat yang sadar tentang kesiapsiagaan bencana.perlu ditingkatkan. 


\section{UCAPAN TERIMAKASIH}

Ucapan terima kasih kami sampaikan kepada pemberi program hibah penelitian tentang Muhammadiyah Angkatan ke 3 yaitu Majelis Pendidikan Tinggi Penelitian dan Pengembangan Pimpinan Pusat Muhammadiyah tahun 2019. Terima kasih juga diberikan kepada Lembaga Penelitian dan Pengabdian Masyarakat STIKES Muhammadiyah Gombong yang telah memfasilitasi kegiatan penelitian, dan kepada partisipan yang sudah memberikan informasi dengan baik.

\section{REFERENCE}

Ahayalimudin, N., \& Osman, N. N. S. (2016). Disaster management: Emergency nursing and medical personnel's knowledge, attitude and practices of the East Coast region hospitals of Malaysia. Australasian Emergency Nursing Journal, 19(4), 203-209. https://doi.org/10.1016/J.AENJ.2016.08.001

Ahmed, N., \& Glaser, M. (2016). Coastal aquaculture, mangrove deforestation and blue carbon emissions: Is REDD+ a solution? Marine Policy, 66, 58-66. https://doi.org/10.1016/J.MARPOL.2016.01.011

Al Thobaity, A., Plummer, V., Innes, K., \& Copnell, B. (2015). Perceptions of knowledge of disaster management among military and civilian nurses in Saudi Arabia. Australasian Emergency Nursing Journal, 18(3), 156-164. https://doi.org/10.1016/J.AENJ.2015.03.001

Alfred, D., Chilton, J., Connor, D., Deal, B., Fountain, R., Hensarling, J., \& Klotz, L. (2015). Preparing for disasters: Education and management strategies explored. Nurse Education in Practice. https://doi.org/10.1016/j.nepr.2014.08.001

Baack, S., \& Alfred, D. (2013). Nurses' preparedness and perceived competence in managing disasters. Journal of Nursing Scholarship. https://doi.org/10.1111/jnu.12029

Baeda, A. Y., Rachman, T., Umar, H., \& Suriamihardja, D. A. (2015). Mitigation Plan for Future Tsunami of Seruni Beach Bantaeng. Procedia Earth and Planetary Science, 14, 179-185. https://doi.org/10.1016/J.PROEPS.2015.07.099

Doondori, A. K., \& Paschalia, Y. P. M. (2021). Peran Perawat dalam Penanggulangan Bencana. Jurnal Kesehatan Primer, 6(1), 63-70.

Esteban, M., Tsimopoulou, V., Mikami, T., Yun, N. Y., Suppasri, A., \& Shibayama, T. (2013). Recent tsunamis events and preparedness: Development of tsunami awareness in Indonesia, Chile and Japan. International Journal of Disaster Risk Reduction, 5, 84-97. https://doi.org/10.1016/J.IJDRR.2013.07.002

Giri, C., Long, J., Abbas, S., Murali, R. M., Qamer, F. M., Pengra, B., \& Thau, D. (2015). Distribution and dynamics of mangrove forests of South Asia. Journal of Environmental Management, 148, 101-111. https://doi.org/10.1016/J.JENVMAN.2014.01.020

Hammad, K. S., Arbon, P., \& Gebbie, K. M. (2011). Emergency nurses and disaster response: An exploration of South Australian emergency nurses' knowledge and 
perceptions of their roles in disaster response. Australasian Emergency Nursing Journal, 14(2), 87-94. https://doi.org/10.1016/J.AENJ.2010.10.002

Hanes, P. F. (2016). Wildfire Disasters and Nursing. In Nursing Clinics of North America. https://doi.org/10.1016/j.cnur.2016.07.006

Husna, C., Hatthakit, U., \& Chaowalit, A. (2011). Do knowledge and clinical experience have specific roles in perceived clinical skills for tsunami care among nurses in Banda Aceh, Indonesia? Australasian Emergency Nursing Journal, 14(2), 95-102. https://doi.org/10.1016/J.AENJ.2010.12.001

Kalanlar, B. (2018). Effects of disaster nursing education on nursing students' knowledge and preparedness for disasters. International Journal of Disaster Risk Reduction, 28, 475480. https://doi.org/10.1016/J.IJDRR.2017.12.008

Kuniayanti, M. A. (2012). Peran Tenaga Kesehatan dalam Penanganan Manajemen Bencana. Jurnal Ilmiah Kesehatan Media Husada.

Labrague, L. J., Hammad, K., Gloe, D. S., McEnroe-Petitte, D. M., Fronda, D. C., Obeidat, A. A., Leocadio, M. C., Cayaban, A. R., \& Mirafuentes, E. C. (2018). Disaster preparedness among nurses: a systematic review of literature. In International Nursing Review. https://doi.org/10.1111/inr.12369

Labrague, Leodoro J., Yboa, B. C., Mcenroe-Petitte, D. M., Lobrino, L. R., \& Brennan, M. G. B. (2016). Disaster Preparedness in Philippine Nurses. Journal of Nursing Scholarship. https://doi.org/10.1111/jnu.12186

Li, S., Meng, X., Ge, Z., \& Zhang, L. (2015). Evaluation of the threat from sea-level rise to the mangrove ecosystems in Tieshangang Bay, southern China. Ocean \& Coastal Management, 109, 1-8. https://doi.org/10.1016/J.OCECOAMAN.2015.02.006

Lindell, M. K. (2013). Disaster studies. Current Sociology. https://doi.org/10.1177/0011392113484456

Loke, A. Y., \& Fung, O. W. M. (2014). Nurses' competencies in disaster nursing: Implications for curriculum development and public health. International Journal of Environmental Research and Public Health. https://doi.org/10.3390/ijerph110303289

Lovelock, C. E., Cahoon, D. R., Friess, D. A., Guntenspergen, G. R., Krauss, K. W., Reef, R., Rogers, K., Saunders, M. L., Sidik, F., Swales, A., Saintilan, N., Thuyen, L. X., \& Triet, T. (2015). The vulnerability of Indo-Pacific mangrove forests to sea-level rise. Nature. https://doi.org/10.1038/nature15538

Maza, M., Lara, J. L., \& Losada, I. J. (2015). Tsunami wave interaction with mangrove forests: A 3-D numerical approach. Coastal Engineering, 98, 33-54. https://doi.org/10.1016/J.COASTALENG.2015.01.002

Nilsson, J., Johansson, E., Carlsson, M., Florin, J., Leksell, J., Lepp, M., Lindholm, C., Nordström, G., Theander, K., Wilde-Larsson, B., \& Gardulf, A. (2016). Disaster nursing: Self-reported competence of nursing students and registered nurses, with focus on their readiness to manage violence, serious events and disasters. Nurse Education in 
Practice, 17, 102-108. https://doi.org/10.1016/J.NEPR.2015.09.012

Paidi. (2012). Pengelolaan manajemen risiko bencana alam di indonesia. Widya.

Park, H.-Y., \& Kim, J.-S. (2017). Factors influencing disaster nursing core competencies of emergency nurses. Applied Nursing Research, 37, 1-5.

https://doi.org/10.1016/J.APNR.2017.06.004

Petrini, M. A. (2014). Mitigation, resilience, and nursing. In Nursing and Health Sciences. https://doi.org/10.1111/nhs.12132

Rasmeemasmuang, T., \& Sasaki, J. (2015). Wave Reduction in Mangrove Forests: General Information and Case Study in Thailand. Handbook of Coastal Disaster Mitigation for Engineers and Planners, 511-535. https://doi.org/10.1016/B978-0-12-801060-0.000241

Rizqillah, A. F., \& Suna, J. (2018). Indonesian emergency nurses' preparedness to respond to disaster: A descriptive survey. Australasian Emergency Care, 21(2), 64-68. https://doi.org/10.1016/J.AUEC.2018.04.001

Rogers, K., Boon, P. I., Branigan, S., Duke, N. C., Field, C. D., Fitzsimons, J. A., Kirkman, H., Mackenzie, J. R., \& Saintilan, N. (2016). The state of legislation and policy protecting Australia's mangrove and salt marsh and their ecosystem services. Marine Policy, 72, 139-155. https://doi.org/10.1016/J.MARPOL.2016.06.025

Saintilan, N., Wilson, N. C., Rogers, K., Rajkaran, A., \& Krauss, K. W. (2014). Mangrove expansion and salt marsh decline at mangrove poleward limits. Global Change Biology. https://doi.org/10.1111/gcb.12341

Saw, A. A., \& Kanzaki, M. (2015). Local Livelihoods and Encroachment into a Mangrove Forest Reserve: A Case Study of the Wunbaik Reserved Mangrove Forest, Myanmar. Procedia Environmental Sciences, 28, 483-492. https://doi.org/10.1016/J.PROENV.2015.07.058

Scholten, K., Scott, P. S., \& Fynes, B. (2014). Mitigation processes - antecedents for building supply chain resilience. Supply Chain Management. https://doi.org/10.1108/SCM-062013-0191

Sierra-Correa, P. C., \& Cantera Kintz, J. R. (2015). Ecosystem-based adaptation for improving coastal planning for sea-level rise: A systematic review for mangrove coasts. Marine Policy, 51, 385-393. https://doi.org/10.1016/J.MARPOL.2014.09.013

Sonneborn, O., Miller, C., Head, L., \& Cross, R. (2018). Disaster education and preparedness in the acute care setting: A cross sectional survey of operating theatre nurse's disaster knowledge and education. Nurse Education Today, 65, 23-29. https://doi.org/10.1016/J.NEDT.2018.02.015

Suwaryo, P. A. W., \& Yuwono, P. (2017). Faktor-faktor yang mempengaruhi tingkat pengetahuan masyarakat dalam mitigasi bencana alam tanah longsor. Urecol 6th.

Tzeng, W.-C., Feng, H.-P., Cheng, W.-T., Lin, C.-H., Chiang, L.-C., Pai, L., \& Lee, C.-L. 
(2016). Readiness of hospital nurses for disaster responses in Taiwan: A cross-sectional study. Nurse Education Today, 47, 37-42. https://doi.org/10.1016/J.NEDT.2016.02.025

Usher, K., \& Mayner, L. (2011). Disaster nursing: A descriptive survey of Australian undergraduate nursing curricula. Australasian Emergency Nursing Journal, 14(2), 7580. https://doi.org/10.1016/J.AENJ.2011.02.005

Veenema, T. G., Griffin, A., Gable, A. R., Macintyre, L., Simons, R. N., Couig, M. P., Walsh, J. J., Lavin, R. P., Dobalian, A., \& Larson, E. (2016). Nurses as Leaders in Disaster Preparedness and Response-A Call to Action. Journal of Nursing Scholarship. https://doi.org/10.1111/jnu.12198

Widayatun, \& Fatoni, Z. (2013). Permasalahan Kesehatan dalam Kondisi Bencana:Peran Petugas Kesehatan dan Partisipasi Masyarakat (Health Problems in a Disaster Situation : the Role of Health Personnels and Community Participation). Jurnal Kependudukan Indonesia.

Yan, Y. E., Turale, S., Stone, T., \& Petrini, M. (2015). Disaster nursing skills, knowledge and attitudes required in earthquake relief: Implications for nursing education. International Nursing Review. https://doi.org/10.1111/inr.12175 